$34 \cdot 1 \mathrm{~kg} / \mathrm{mm}^{2}$ を示し獨逸の愹接規格 DIN 4100 に合格す る。故に繰这し力を受ける場合には單に抗張力大なるのみな らず氝泡なく、链面の變化急激ならざる熔接をなすことを 心掛けねばならぬ。第 2 圖はその例で波勞限界 $18 \mathrm{~kg} / \mathrm{mm}^{2}$ を示した。此の事賽 よりして哭合せ熔接 の抗張力は大して意 味のないもので、熔 接部遑喕形狀及內部 品質が重大となる。 熔接部に著しき高き 抗張力を望むよりも 母材に近き品質を望 むことが適當でその 理由は次の樣であ る。熔接部は仕上な いで使用するのが普 通であるから母村の 卧面に切込久影響を 與一る結果となり、 占き試驗の結果に依 ると切込を有する强力の鋼は 動的外力を受けた時 St 37 と 问樣の抵抗を有するのみであ るから鋼の構造物等に於て充 分强力の繰返し抵抗を必要と する際は侧面又は前面隅肉熔 接をなすが普通である。何と なれば此れに於ては熔接の久 熙が大した影響を與へないか らであるが、然るに第3圖に 示寸如く突合熔接よりも内力 集中箸しく、低き繰返し内力 で折損せるを認める。その理 由は中央本鋼の片側が伸ばされその部分に小さい割れが生じ 繰返しと共に進行するからである。

(山口)

\section{[64] ハンマ端部をアセチレン盛金する方法}

[Soderstrom, Weldg. Engr., Vol. 18, No. 12, 1933-12, 頁 287

一寸した問題であるが熔接に依り工具の修繬再用を岡る間 題の例として此處に紹介する。ハンマ端部をガス盛金し、鉬 造し、燒入燒戻す る。圖の左は修綀 を要すべきもの、 中央は加修品、右 端は加修後 2 ケ年 使用せるすのを示 す。加修方法は次 の通りである。制

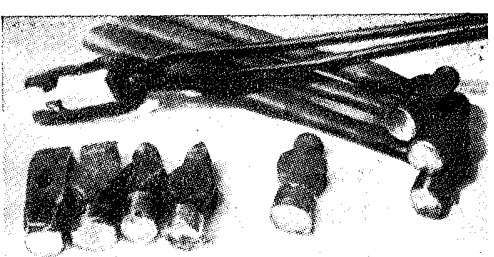

第 1 圆

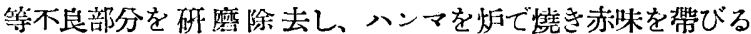
程度に加熱してj゙ス盛金するのであるが、棒は工具鋼棒を用 ひ少量のフラックスを用ひる。此の際後退熔接を用ひるとカ スのため熔鐵が酸化堂化されず過熱されることがない。盛金 後均一に加熱燒鈍する。更に黃赤色に加熱し、銀造、燒钝の

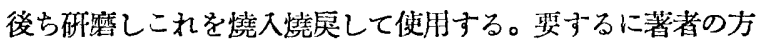
法に体り適當の鋼を盛金し熱處理することに依り常に起る所 のハンマのムシレをなくしハンマの壽命を大とし從つてムシ レが飛散し傷害を起すことを無くすることが出來る。

(山口)

\section{[65］新らしきガス切斷機械}

[Weldg. Engr., Vol. 18, No. 12, 1933-12, 頁 30]

萿らしきガス切断機が Pantosec の名稱で Linde Air Products Co. から賣出された。本機は一方向に 44 in 他 の方向には 20 in の使用籁圍を有す る。直線、3 角、 円その他複雜な形 狀に切断出來る。 特長としてカム等 の如き平滑且つ正 確な切断を要する 場合に適する。臺 は 3 品にて芰へら

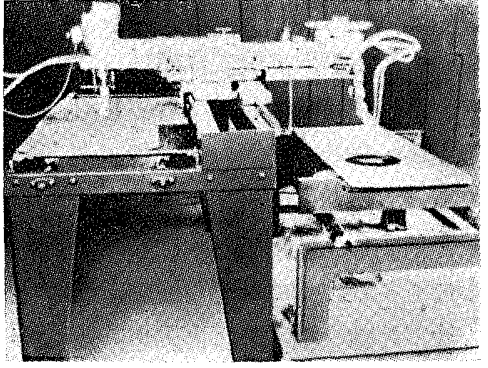

第 1 圖 Pantosec ガス切断機 れ吹管は目動又は手動で運ばれ、形板を用ひ得。（山口）

\section{[66] 直徑 30 呎管の電㲴熔接}

[Chester B. Lord, Am. Macht., 1933-1220, 頁 305]

單に品物が非常に大きいからと云つても特筆する理由はな いが、種々の點に於て新方法を考案した所があるので此處に 紹介する。Boulder Damは 17 基の水力タービン（總出力 1,800,000 馬力) を有し、B1ack Conyon から導水する水道 管が Babcock \& Wilcox 會社 (New York) で作られ、其 の寸法は次の通りである。

\begin{tabular}{|c|c|c|c|c|c|}
\hline 長さ $\mathrm{ft}$ & 㨁徑 $\mathrm{ft}$ & 厚さ ins & 長さ $\mathrm{ft}$ & 直徑 $\mathrm{ft}$ & 厚さ ins \\
\hline $\begin{array}{l}4,700 \\
1,900\end{array}$ & $\begin{array}{l}30 \\
25\end{array}$ & $\begin{array}{l}1 \frac{11}{16}-2 \frac{3}{4} \\
1 \frac{5}{8}-2 \frac{5}{16}\end{array}$ & $\begin{array}{l}5,600 \\
2,300\end{array}$ & $\begin{array}{l}13 \\
81\end{array}$ & 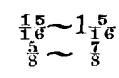 \\
\hline
\end{tabular}

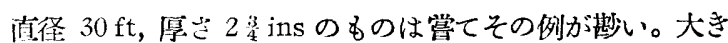
い舶用罐でさ一此の直径のものはない。舶用罐の場合は板の 緣に鋲穴を錐搡し、ボル下締して取㧞らのが普通である。水

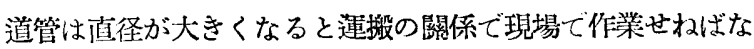
らない。Illinois Steel Co. が銅材を圧延したが $32 \times 12 \mathrm{ft} \times$ $2 \frac{3}{4}$ in は区延及渾搬出來万最大のもので、1 枚の重量は $23 \mathrm{t}$ で貨車 1 輛に 2 枚䗃せ得、板の總重量 45,000 t を要した。 此等の板 3 枚を曲げ長さの方向に繼合せ直径 $30 \mathrm{ft}$ 長导 $12 \mathrm{ft}$ の輸 1 筒を作り、之等 2 䉪及繼目板を熔接して 1 組の素の 輪が出來る。その 1 筒の輪を第 1 圖に示す。現場作業として

[第 37 卷第 204 號 